\title{
BOERHAAVE'S BIOCHEMISTRY
}

\author{
by \\ F. R. JEVONS
}

ON Boerhaave's portrait, ${ }^{1}$ the rotund and jovial face, the cheerful eyes and gentle, good-humoured smile suggest the genial disposition which doubtless contributed much to his immense popularity as a teacher. This was the man who, during the winter, would give weekly musical parties, himself performing with voice, lute and other instruments; and who ate his food with an honest enjoyment to which his tall, corpulent frame bore witness-though, careful of his purse as well as of his health, he gave rein to his great appetite only at dinner, and instead of wine drank mostly water and the oat-ale called moll. ${ }^{2}$ Around the face on the portrait run the words, HERMANNUS BOERHAAVE BOT. GHEM. \& MED. PROF. IN AGAD. LEID. REGG. SOCG. LOND. \& PAR. SOC. The inscription epitomizes two further important facts about him: the breadth of his scholarship, indicated by his tenure of chairs of chemistry and botany as well as medicine, and international recognition by the world of learning, represented here by the two outstanding scientific societies of the day. The reputation of this 'Batavian Hippocrates' was such that Leyden in his day was undoubtedly one of the most influential medical schools not only of that, but of any age. Students flocked thither from all over Europe, and from the seeds liberally scattered by the great teacher grew much of the medical glory of Edinburgh and Vienna, not to mention the immense reputation that Haller made both for himself and for the University newly founded by George II at Göttingen. Among the plentiful evidence of Boerhaave's fame, his biographer delighted especially in the story of 'Peter the Great late Czar of Muscovy; who did not repent lying all night in his pleasure barge against Boerhaave's house, in order to have two hours conversation with him on various points of learning the next morning before college time'. ${ }^{3}$

Boerhaave's interest in chemistry dated from the early $1690 s$, when he first studied medicine. At that time, he already had behind him a degree in philosophy and an education unusually broad by the standards of any age. At the University of Leyden he had eagerly imbibed logic, geography, natural philosophy, metaphysics, ethics, rhetoric and chronology; among the ancient tongues, he had mastered not only Greek and Latin but also Hebrew and Chaldee; 'till perceiving the necessity of mathematics', in a way so characteristic of the time, he had found the greatest satisfaction in the geometry of the ancients as well as the algebra of the moderns-all this quite apart from the divinity which qualified him as a preacher. ${ }^{4}$ Still unsatisfied, however, he spent his early twenties studying medicine, including its auxiliary subjects chemistry and botany. ${ }^{5}$ Chemistry in particular, 'the key to nature', captivated him, and he learned much that could not be got from books from a friendship with the chemist Stam. His brother James was his companion in these early studies; years later, in dedicating the Elements of Chemistry to him, Herman gratefully 


\section{F. R. Jevons}

recalled 'how many Days and Nights we have spent successively together in the chemical Examination of Natural Bodies. At that time, indeed, your Thoughts were turned chiefly to Physick, mine to Divinity: but Providence ordered otherwise." ${ }^{16}$ The two brothers were, in fact, to interchange careers. Herman, on the boat returning to Leyden after taking his doctorate in physic at Harderwijk in I693, got embroiled in a philosophical discussion about Spinoza and inadvertently gave the impression of being an adherent of that philosopher, whose pantheism seemed tantamount to atheism in the eyes of many; fearing on this account to be refused a licence to preach, he practised medicine instead.

\section{Chemical Teaching}

When he began to teach in I 70r, he soon showed his keen awareness of the applicability of chemistry to medicine. 'Boerhaave's pupils could not but observe in his lectures on the medical institutions how judiciously he interspersed chemistry, so as to render this art, by his singular application of it, subservient to the illustration of them, and were thereupon so delighted with their preceptor and his doctrine, that they ceased not requesting, till by dint of importunity alone they prevailed with him, to instruct them in chemistry, as well as in the

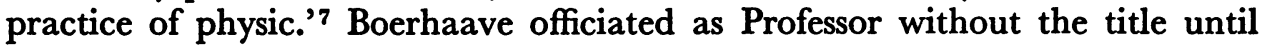
1709, when he received the chairs of medicine and botany on the death of Hotton; in 1714 he succeeded Bidloo in the chair of the practice of physic, a post involving clinical instruction in the University hospital; his lectures on chemistry, however, remained private until Le Mort (author of Chymia Medico-Physica, Leyden, 1696) died in 1718. From that date he held the four chairs simultaneously until 1729 , when he relinquished those of chemistry and botany. Ill-health helped to induce him to resign, for he was again attacked by the crippling arthritis which had first seized him seven years earlier, but there was also another reason which, as it turned out, was closely connected with the appearance of his Elements of Chemistry. It had not been his intention to publish a textbook of chemistry, but to his dismay he found that some of his pupils, taking advantage of 'the insatiable Avarice of some Booksellers', ${ }^{8}$ published a version of his course under his name. He disowned this 'miserable Performance' indignantly. Its publishers, he complained, 'thus did an Injury both to the Publick and me, in a manner certainly very dishonourable, and that ought to be taken notice of by the Laws. The false Notions, Absurdities, and Barbarisms, that are imputed to me in every Page of that Work, are so abominable, that they will not bear mentioning.'9 Such, however, was the reputation that his name carried that the 'sorry Book' was a resounding success, and he had the 'daily Mortification' of seeing it in the hands of his pupils at his lectures. In vexation at his failure to goad the authorities into action against it, he determined to stop giving his course on chemistry. Meanwhile, demand for the spurious work continued so strong that its price went up and a reprinting threatened; eventually, therefore, he allowed himself to be persuaded for his own protection to publish his course himself, and it appeared in its original Latin version in $\mathbf{I} 732$. 


\section{Boerhaave's Biochemistry}

What appears most plainly from the Elements of Chemistry is not Boerhaave the innovator breaking new ground, ${ }^{10}$ but Boerhaave the polymath and, above all, teacher. The book is repetitious and, as the English translator confesses, 'in many places pretty prolix', running to over 900 quarto pages in the English translation. These qualities were justified, however, by its origin from lectures in which it was necessary 'to dwell longer upon Things', and by the need, when. the time came, to publish quickly, allowing little opportunity for 'retrenching these Superfluities'.11 The result is that the scene in Boerhaave's lecture theatre is brought more vividly before us than the conciseness of a more orthodox textbook would allow. We see him exhibiting many specimens in Plates, with proper Inscriptions', ${ }^{12}$ and often demonstrating operations before his audience. 'But please to attend carefully now to the following experiment, which is pretty surprizing' he says, with the glee of a lecturer who has a good trick up his sleeve, when he mixes egg white, nitric acid and potassium carbonate, and notes 'what a furious Ebullition is excited, and how prodigiously they rarefy, so as to run out of the Vessel though it is ten times as big as would contain them'.13 How different from his textbooks of the theory and the practice of medicine! These works, the Institutes of Medicine and the Aphorisms (original editions I 708 and I 709 respectively) consisted of little more than the subject titles used as a basis on which to enlarge in lectures; they invited the publication of versions in various languages with extensive commentaries which, based only on students' lecture notes, were often inaccurate enough - though eventually the one was fortunate enough to be put out under the authority of Haller, the other with the diligence of Van Swieten.

\section{Chemistry applied to Living Things}

Boerhaave's views on the chemistry of living organisms were given added weight by his authoritative status in chemical as well as biological matters. On the other hand, a very different attitude was being taken in Prussia by a man with an equally impressive dual qualification. Stahl was physician to Friedrich Wilhelm I and at the same time one of Europe's foremost chemists, the principal propagator of the phlogiston theory. Despite the difficult style of his voluminous writings, his influence increased rapidly. The very starting point of his doctrine was the uselessness of trying to apply to medicine the ideas of chemistry and of mechanics; greater familiarity made his rejection of the former more convincing than of the latter. Those supposed changes in the composition of the body fluids, to which over-enthusiastic iatrochemists like Sylvius and Willis had attributed diseases, could not actually be observed by Stahl. It is not because of its composition that the body is alive; quite on the contrary, he pointed out, the composition of the body is highly corruptible, and left to itself it soon decaysits conservation is the essential act of life. Impressed by the self-preserving power of the forces regulating life, as manifested especially in the reactions of the organism against disease, he felt the need to postulate some cause endowed with intelligence to direct the bodily processes in a purposeful way, and such a principle he found in the rational soul. This, for Stahl, was not merely a mental 


\section{F. R. Fevons}

concept, but a real power which organizes and rules matter without itself being material. The absence of understanding and intelligence made the phenomena of chemistry and mechanics appear to him an unsuitable basis for explaining the facts of physiology. He entirely rejected-and with ample justification-those iatrochemical doctrines then current which related processes in the body by wild analogies to effects observed in vitro, condemning all such attempts to 'see through' instead of conscientiously observing the phenomena proper to life. ${ }^{14}$

Boerhaave had a similar respect for observations made directly on living material, but beyond that there was little similarity between his approach and Stahl's. No wonder he preferred the writings of Hoffman, Stahl's erstwhile colleague at the University of Halle and his redoubtable opponent in debate on physiological doctrine; students at Leyden were recommended to read 'above all, the very ingenious Frederic Hoffman'. ${ }^{15}$ To Boerhaave, chemistry was a necessary part of physiology. 'Those vain, trifling Chemists, were certainly in the wrong, when they pretended by their Art alone to explain physiology in all its parts; nor however are they less mistaken, who imagine they can do the same thing without it'. The chemists, with their effervescences, fermentations and fires, formed one of the two principal sects in medicine at the end of the seventeenth century; the other was the mechanical, with its matter and motion. The judicious pruning of the extravagances of these two bodies of doctrine, and their relatively successful fusion, were important ingredients of Boerhaave's success. With mechanics to examine the solids, hydrostatics to give the laws of fluids in general, and 'that beautiful Science Hydraulics' to explain their actions as they move through canals-add the chemists' discoveries to these, 'and then, if I am not mistaken, we shall have a complete account of the physiological part of Physic'. ${ }^{16}$ Chemical matters do not dominate, but nevertheless pervade the Institutes; in the Aphorisms they figure if anything more prominently. Conversely, a relatively strong emphasis is given to biological matters in the Elements of Chemistry; in the practical part devoted to operations, I 95 pages deal with vegetables, 6 I with animals and I05 with 'fossils' (minerals). In Lemery's immensely popular textbook, ${ }^{17}$ for comparison, the corresponding sections occupy 130,43 and $33^{\circ}$ pages respectively, and are largely preoccupied with the preparation of medicines. Clearly, chemistry meant much more to Boerhaave than a route to more convenient or more efficacious drugs; it was closely interwoven with anatomical and mechanical considerations to form an integrated structure of physiological and pathological explanation. It offered itself as the handmaid of medicine as a whole, not of pharmacy only.

\section{Scientific Method}

Boerhaave paid lip-service to the effect of mind on body, but in effect treated the latter as functioning independently. In this, his physiology resembled the Cartesian, in which the body acted like a machine, with a special proviso in the human case for the power of mind to direct voluntary movements. Boerhaave's general scientific method, however, was very unlike that of Descartes. Since that philosopher's time, there had appeared the Essay on the Human Understanding, 


\section{Boerhaave's Biochemistry}

whose author, Locke, was the friend of Boyle, one of Boerhaave's idols. Much of science had lost that over-confidence about all-embracing certainty which Cartesianism had in common with medieval systems. Empiricism was deeply rooted in Boerhaave, and he fully recognized limitations to knowledge.

Starting with the most sweeping doubts, Descartes had made perhaps the most celebrated attempt in the history of philosophy to attain certainty. ${ }^{18}$ Yet the sort of certainty he attained in his universal physics and its extension to physiology was of a peculiarly limited kind. How certain could he be of his contentions that the heart acts by a mechanical process which we might now compare with that of the internal combustion engine, droplets of venous blood being vaporized by its innate heat and driving all before them in their expansion; or that tiny threads running in hollow nerves convey impressions from sense organs to the brain?19 Certain that it is possible, given gross appearances and the laws of mechanics; but not certain that it is really so in the body. Descartes, in fact, was arguing only indirectly, by analogy; despite his claims to have spent much time on the direct study of animals, he was really only indulging in the parlour game, which has remained fairly popular ever since, of imagining inanimate models to imitate the superficial behaviour of living organisms.

This was not good enough for Boerhaave, for whom direct observation was the touchstone of certainty, and progress possible only by means of experiments, and by mathematical reasoning on the observed results. 'As to Des Cartes, it is hardly credible, that such excellent mathematical treatises, as those on geometry and dioptrics, and so different performances on physics should proceed from one and the same author; and the like difference is observable betwixt the mathematical writings of Huygens, and his Cosmotheoros, wherein he indulges imagination.' But scepticism need not extend to the trustworthiness of observations, only to 'the wild licentiousness of assuming principles for explaining observations.20 Boerhaave maintained a steadfast agnosticism about the primary constituents of things; from the fact that the universe still appears to be much the same as thousands of years ago, despite the continual changes of growth and decay, he argued that indestructible atoms must exist, but since they are too small to be perceptible by the senses, nothing more is known about them. ${ }^{21},{ }^{22} \mathrm{He}$ proclaimed 'the necessity of collecting naked and indisputable facts, and delivering them untainted by partiality or hypothesis', ${ }^{23}$ and set up Francis Bacon as his greatest hero after Hippocrates. ${ }^{24}$ In fact, of course, he did not practise quite the extreme empiricism that he preached. In praising Hippocrates for his faithful collection of the signs and symptoms of diseases, and ' $h$ is regard to evident, before occult causes' ${ }^{25}$ he conveniently disregarded the dogmatism that has been so evident to others in the writings of the school of Cos. Certainly, although he admired Sydenham, he did not take clinical empiricism to the same length of leaving anatomy and botany to the butchers and the flower-sellers of Covent Garden, in order to concentrate on the bedside. Then again, while Boyle, on whom he heaped praises as the outstanding practitioner of Baconian method, ${ }^{26}$ was noticeably less successful at formulating theory than at demolishing it, Boerhaave was himself a most considerable 


\section{F. R. Fevons}

systematizer, and the teaching quality of his works owes much to the coherence and consistency of his doctrines.

He was exercised about the interrelations of particular and general, and criticized both the Cartesian mechanists and the chemists for mishandling the problem, though in different ways. The mechanists 'incumbered it (medicine) with useless fictions, by fleeing so hastily from generals to particulars'.27 The chemists, on the other hand, while they had done useful work in discovering the observable and therefore certain properties and interactions of substances, 'are miserably mistaken in the general laws, to which from their particular experiments they conclude all bodies to be subject . . . their cant of elements, fictitious ferments, effervescences, antagonist salts the only engines of nature'. ${ }^{28}$ Despite Boerhaave's differentiation between the two methodologies, however, the procedure of the chemists followed principles in essence closely analogous to those of the mechanists, and the epistemological value of their conclusions was correspondingly similar. Both sects argued essentially by analogy from inanimate model systems to events in living bodies. But whereas the mechanists were at least not mistaken in seeing matter and motion in animals, the chemists had to imagine their effervescences, for they were unfortunate enough to have picked on that ill-fated theory of seventeenth-century chemistry, the acidalkali hypothesis. ${ }^{29,} 30$

\section{Refutation of the Acid-Alkali Physiology}

The 'acid' and 'alkali' of the hypothesis, of course, were concepts very different from the modern ones that go by these names. They were two fundamental and opposing principles of matter, a duality to supplement or replace the older tria prima of Paracelsus and the ancient Aristotelian quartet of elements. Thus, Tachenius proclaimed that 'all Sublunary Bodies (Experience being witness) do consist of two things, Acid and Alcaly, as I shall mechanically shew in this Tract'. They were the essence of all things, antagonistic by nature and inevitably reacting when brought together, acid being the dominant principle, for 'Acids do attract Alcalyes at their pleasure, and rule over them as they list'. ${ }^{31}$

Although the acid-alkali theory later found a more congenial home in inorganic chemistry, it was in physiology that it originally gathered its strength. Van Helmont, ${ }^{32,}$ 33, 34 when feeding sparrows as a boy, had let them get hold of his tongue and noticed a sharp, sour taste in the throat of the birds. Later, he saw that some acid sulphurous substance partly liquefied his glove. Since vinegar alone failed to digest bread in vitro, he recognized that ordinary acid could not be the sole cause of the first of his six digestions (that in the stomach), but he did consider acid to be closely related to the true instrument and its chief agent. He held excess of acid to be responsible for discomfort and illness, the bile being then inadequate to turn it into salt. ${ }^{35}$ Further, he carried over the idea of the importance of acid into a wider pathology, supposing, for instance, that pleurisy arises from acid which causes pain in the intercostal muscles; this was deduced by him from his assertion that blood drawn in this 


\section{Boerhaave's Biochemistry}

disease clots immediately, due to the acid, and he concluded that treatment should be not by bleeding but by 'more specific means'. Similarly, he attributed pus in wounds to acid which coagulates the nutriment, and recommended alkali as antidote. The mid-seventeenth-century argument was put with charming verbosity by Dr. Walter Charleton, ${ }^{36}$ 'physician to the late King', who apprehended an 'exotick Acidity . . . to be the sole Impediment [to healing]. . . . Thus in many wounds, all the vigor of Nature cannot suffice to the ejection of that forein Acor [but] upon the first charge the usurper must surrender at the access of a Lixivial Traumatick Salt. ${ }^{\text {'37 }}$

It was Sylvius, Professor of Medicine at Leyden from 1658 to 1672 , who did most to extend the idea of the physiological role of acid and alkali. Like Van Helmont, he took the phenomena of wine and beer fermentation as an illustrative analogy to changes in the animal body, but he was mesmerized not so much by the transformation undergone by the liquid itself as by the bubbling and frothing of the accompanying evolution of gas, which seemed to him the essential feature of the whole process-so much so that he came to use 'effervescence' synonymously with 'fermentation'. Now Sylvius knew that effervescence can be produced in the laboratory by the interaction of an acid and an alkali-and it must be remembered here that the typical and most common alkali of the seventeenth century was potassium carbonate. ${ }^{38}$ The agitation of the liquid and the escape of gas seemed to him the outward and visible signs of 'strife' between the antagonistic principles of acid and alkali. Thus, in the theories of Sylvius, the four processes of 'digestion' (meaning the whole conversion of foodstuffs into body tissue), fermentation, effervescence and acid-alkali neutralization were inextricably confused, so as to become virtually a single concept.

There were two principal tests by which Sylvius distinguished acids and alkalis. One relied on taste, acids being sour and alkalis bitter; the other was effervescence on mixing with anything commonly regarded as belonging to the opposite category. The reliability of these criteria naturally left much to be desired, as strikingly illustrated by the fact that, while Sylvius had maintained the bile to be alkaline and the pancreatic juice to be acid, there had been another sect that wanted them the other way round. ${ }^{39,} 40$ Boerhaave had a third type of test at his disposal-the use of vegetable indicators. References to a variety of such indicators were scattered through Boyle's Experimental History of Colours, published in 1664, and Boerhaave often mentioned the use of plant extracts turned red by acids and green by alkalis, such as syrup of violets, of roses and of turnsole (Heliotropium tricoccum). ${ }^{41}$ These were very useful to him, but he did not attach over-riding importance to them, for he disqualified ammonia from the ranks of alkalis for its failure to effervesce with acids. ${ }^{42}$ His repudiation of the acid-alkali physiology was achieved less through better chemistry than by a characteristic insistence on direct observation, by discarding 'a prejudiced Notion and Hypothesis' in favour of 'ocular Demonstration'. ${ }^{40}$

He attached great importance to this repudiation. 'But the greatest glory of this valuable Art [chemistry] consists in its being able to discover and correct 


\section{F. R. Fevons}

those errors, which some whimsical dablers in Chemistry had introduc'd into Medicine.'16 Time after time he gave details of negative tests for acid and alkali on fluids fresh from healthy animals-saliva, stomach liquor, bile, pancreatic juice, milk, urine, egg white and blood serum. ${ }^{43}$ The experiment with egg white, nitric acid and potassium carbonate, referred to above as a lecture demonstration, was in fact a searching control of a type he applied also to milk and to serum; the biological material does not effervesce with either the acid or the alkali alone, but, far from inhibiting the effervescence these produce with each other, it appears to promote it (by stabilizing the foam). On one point, of course, he went too far-in denying a gastric acid. He reported the stomach liquor to be 'a little saline, being neither acid nor alcaline'. Cosmus III, the Grand Duke of Tuscany, had given voracious animals such as falcons, eagles, vultures and swans to be opened in the presence of Malpighi, Borelli, Read, Finch and Steno, and this impressive galaxy of authorities found only 'a very mild juice, of a muriatic Taste'. ${ }^{44}$ The failures to find acid were presumably due to the use of fasting stomachs; 45 acidity after eating was attributed by Boerhaave to foodstuffs turning sour, and he explained away Van Helmont's observation in this manner. An acid-generating fermentation seemed an inevitable and normal consequence of keeping vegetable food warm and moist in the stomach, ${ }^{46}$ and saliva, he said, promotes this even better than water, as 'will also appear from the frequent Rumblings and Belchings of Air'. ${ }^{47}$

While admitting that bile on putrefaction turns alkaline, Boerhaave denied that it is alkaline originally, any more than barley inebriates before being made into ale. ${ }^{39}$ As for the pancreatic juice, De Graaf himself, mere student though he was, could not 'so far relinquish the Truth, even under the Eye of his Preceptor Sylvius, but that he confessed the pancreatic Juice was often saline, sometimes insipid, very often saltish and a little acid, and sometimes only appearing entirely acid'. 40 Thus fell away the main props of the theory of the acid-alkali 'fermentation' which had been supposed to separate the more fluid parts of the chyme from the more earthy and feculent, the former of these two fractions being absorbed by the lacteals while the latter passed down the intestines. ${ }^{39}$

De Graaf, however, had a way out of the difficulty that bile and pancreatic juice do not effervesce when mixed outside the body; he took refuge behind a supposed heat in the intestine different from any produced artificially. ${ }^{48}$ The concept of temperature, as well as the technical problems of measuring it, were still major difficulties even to Boerhaave later. ${ }^{49}$ The situation was clearly fraught with the usual objections to arguing from in vitro to in vivo conditions, and there was considerable merit in the suggestion by Schuyl, Professor of Botany at Leyden, of an experiment involving an appeal back to the living animal. This consisted in ligating the duodenum of a dog above and below the bile duct, and replacing it in the abdomen; a few hours later, it was found tense, distended and hot, and upon being cut 'discharg'd a Froth and great Stench; so that it is thus manifest by ocular Demonstration, that the Bile and pancreatic Juice do effervesce upon mixing in the Animal'. Boerhaave, however, was able 
to point out the flaw in the experiment-'that the same Appearances would have been produced by making the Ligatures in any other part of the Intestine . . . from the elastic Air generated by the Fermentation of the intercepted or stagnant Chyle'. Nor was he much impressed by Sylvius's contention that the pancreatic acid might be latent, 'for such an Acid, as is not of a sufficient Strength to discover itself by Appearances, cannot be the Cause of so strong an Effervescence as is assigned to it by Sylvius'.40

The idea of the effervescence on the right side of the heart, arising from the supposedly acid chyle, lymph and pancreatic juice coming up the thoracic duct and meeting the supposedly alkaline bile and blood, ${ }^{50}$ was disposed of by Boerhaave in similar style. Besides again denying the presence of acid or alkali in pancreatic juice and bile, he did the same for milk, which he took as an approximation to chyle diluted with lymph, though brought somewhat nearer a perfect animal nature; ${ }^{51}$ he denied the presence of any kind of bile in the blood, ascribing the yellow colour of serum to the red globules in it, and the blackness of the lower part of the crassamentum or clot to lack of contact with air; 52 and he argued that, even if there were an effervescence in the duodenum, it could hardly be imagined to 'be continued through so many Turnings and Windings, especially after being diluted with so large a Quantity of insipid Lymph', and to exert a force as strong as that of the heart-beat. In the state of Van Helmont's knowledge, he allowed, the postulate of effervescence as the source of heat and motion in the body had been reasonable enough, but 'those errors were more excusable in Helmont than in Sylvius, who was an expert Anatomist, and well acquainted with the Circulation of the Blood'. ${ }^{50}$ Boerhaave was mesmerized by this discovery of Harvey's, like all physiologists, and convinced that the origin of animal heat is the friction of the fluids moving through the vessels.

The formation of urine was to Boerhaave a purely mechanical process, driven by the force of the heart urging the blood through the vessels of the kidney. $\mathrm{He}$ found it unnecessary to assume, with some of the iatrochemists including Willis, that the process involves precipitation of the grosser parts of the blood by an acid, as in the curdling of milk. ${ }^{53}$

As for muscular contraction, working on the assumption that the fibres are composed of chains of bladders or cylinders, he could see no other cause of motion than 'a very thin fluid Body ... forcibly thrust into or applied to the Muscle'. ${ }^{54}$ Sylvius had ascribed 'a subacid Nature' to this fluid, but Boerhaave 'could see no reason why the nervous Fluid, whose Subtilty escapes our Examination, should be rather esteemed an Acid than any other Fluid in the Body'; ${ }^{40}$ he was 'concerned' that Borelli and Bellini had believed the distension and consequent shortening of muscles to be due to the effervescence of an acid spirit of the nerves with an alkali. Likewise, he rejected Willis' variant of the theory, in which the partner of the acid animal spirits was 'oily', meaning combustible. The English school, with their leaning towards combustion, had come somewhat nearer the mark with Mayow's nitro-aerial spirit 'fermenting' with saline-sulphureous (i.e. combustible) particles in the blood and muscles; ${ }^{55}$ 


\section{F. R. Fevons}

the particular in vitro process on which Willis had seized for an analogy was the explosive effervescence on mixing concentrated sulphuric or nitric acid with alcohol. Apart from the lack of evidence for acid or alkali in the fluids concerned, Boerhaave asked how the vessels could resist corrosion by them if they were present, how the fabric of the muscles could stand up to explosions of the kind envisaged by Willis, and how the mind could regulate any such processes. ${ }^{56}$

\section{Caution in Organic Analysis}

Van Helmont had been proud to call himself Philosophus per ignem, and a preoccupation with fire lingered among chemists. To Boerhaave-who, it is true, interpreted 'fire' so as to include heat-it remained not only the topic of greatest interest in the theory, but also the most important instrument in the practice of chemistry ${ }^{57}$ Several times he included the action of fire in definitions of chemistry; for instance, 'Chemistry acquaints us with those Changes which arise in Bodies from Mixture, and the Application of them to Fire'. ${ }^{58}$

Since the destructive nature of chemical operations has been a source of trouble in biological theory right up to the twentieth century, ${ }^{59}$ it is interesting to note the scrupulous care with which Boerhaave set about applying different degrees of heat as his major analytical tool. Awareness of the fact that heating may change as well as separate the constituents of substances had been growing during the second half of the seventeenth century. Boyle's influential voice had pointed to this danger; the preface to Lemery's textbook claimed that 'this Author is one of the first ... to suspect the influence of Fire on the chief Preparations made with it'. ${ }^{60}$ Boerhaave found that even Van Helmont had warned that the Ens specificum is altered by fire, so that medicinal qualities are often lost during the preparation of extracts and magisteries. ${ }^{61}$ Students at Leyden were told to beware the chemists who 'pretend by their Art to be able to exhibit to you those parts of Vegetables in which their particular vertues consist, without a mixture of any of the other parts with them'; the methods available-distillation, fermentation, putrefaction and combustion-produce such considerable alterations. ${ }^{62}$ Accordingly, the first few chemical operations given by Boerhaave were a carefully graded series of heat treatments of a plant, green rosemary being exposed successively to warm air at $85^{\circ} \mathrm{F}$, to boiling water, and to fire with or without access to air; the ideal was that, to begin with at least, nothing more should happen than that the 'native parts are gently separated'. ${ }^{63}$ Exhortations to avoid 'empyreumatical Taints' accompany the instructions for preparing native plant oils. ${ }^{64}$

The seventeenth century variations on theories of elements were mostly based on the dry distillation of materials such as wood. ${ }^{30}$ While Boerhaave did not trouble himself with speculations about ultimate elements, the terms in which he described organic analyses did in fact bear the same names as the five principles Lemery had chosen ${ }^{65}$ - water, spirit, oil, salt and earth. A spirit meant to him something very volatile and elusive, miscible both with water and with oil, and typified by the Spiritus Rector rather than by spirits of wine, whose inflammability was attributed to the presence of a thin oil. ${ }^{49}$ Anything 


\section{Boerhaave's Biochemistry}

combustible, or organic in the modern sense, was included in the meaning of an oily or pinguious material, so that sugar, for instance, was referred to as an oily salt. ${ }^{66}$ An oil showed its presence by smoke, flame and charring on the application of heat; air as well as fire was needed to separate it completely from the ashes, since the residue on heating in a closed vessel remained black. ${ }^{67}$ Salts could be extracted by water either before combustion by making a decoction, or by lixiviating the ashes. The word 'salt' had, during the seventeenth century, lost the implication it had carried as one of the tria prima, of something resistant to fire, for volatile kinds of it (like ammonium carbonate) were now recognized, and the fixed kinds were typically fusible. ${ }^{68}$ Solubility in water and a taste were characteristic of salts, and they could be neutral like sea-salt, acid like tartar, or alkaline like potash. The water-insoluble residue of the ashes, tasteless and not fusible, represented earth.

For all its shortcomings, analysis by destructive distillation did yield a certain amount of significant information. Boerhaave was able to back his conclusion that 'the White of an Egg, and the Serum of Blood, are very nearly of the same nature' by the detailed resemblance of the products successively obtained on raising the temperature, a more searching test to supplement their similar susceptibilities to coagulation by the temperature of boiling water and by concentrated alcohol. ${ }^{69} \mathrm{He}$ clearly did believe that in some limited sense the products of his analyses were genuine constituents of the starting materials. To have shown what living bodies are composed of seemed to him one of chemistry's major achievements. ${ }^{26}$ The fact that simple water can be got from the apparently driest wood elicited the surprised remark that elements can give rise to compound bodies very unlike them..$^{70} \mathrm{He}$ attributed the soap-like properties of plant and animal juices to their oil and salt forming a native $s a p o,{ }^{71}$ and was particularly impressed that the ratio of these obtained from bile was nearly the same as that used for making common soap, which helped account for its efficacy in disposing oily and aqueous parts of the food to mix. ${ }^{39}$

Nevertheless, he was well aware that the fractions he obtained by the stronger degrees of heat were not in the native form, and often re-emphasized that resynthesis of the starting material from such artifacts was impossible. ${ }^{72}$ One obvious indication of change during distillation was the increase in volatility; thus, the volatile alkaline salt from egg white and blood serum, which originally came over only above $300^{\circ} \mathrm{F}$, could then hardly be prevented from flying off even at $3^{\circ}{ }^{\circ},^{73}$ and waxes became attenuated into liquid oils. ${ }^{74}$ The alkaline fixed salt in vegetable ashes was also recognized as an artifact due to heat, for the salts crystallized from native or fermented plant juices were often acid (e.g. salt of sorrel and tartar of wine ${ }^{75}$ ).

These effects of fire were not merely of academic interest in chemical theory; they carried far-reaching implications for physiology and pathology.

\section{Assimilation of Food}

While Boerhaave regarded the matter of plant and animal bodies as fundamentally similar, the food of the latter being derived directly or indirectly from 


\section{F. R. Fevons}

the former, ${ }^{76}$ he recognized one important difference between them. Most plants tend to ferment, turning sour and acid, while animal flesh tends to putrefy and afford a volatile alkali. ${ }^{46}$ The distinction was based on sound observation, resting broadly on the behaviour, in modern terms, of predominantly carbohydrate and predominantly protein material respectively; the acid-forming propensity of sugar retains a place in present-day dental theory. Boerhaave recognized that some plant materials, including various bulbs, fleshy roots and seeds, resemble animals in their disposition to putrefy rather than ferment. The difference was also discoverable by dry distillation in a closed atmosphere, most plants giving an oily acid salt or 'vinegar', while animal and the exceptional plant matters gave an oily alkaline salt. ${ }^{77}$ The starting materials being usually neither acid nor alkaline, Boerhaave referred to them as 'acescent' and 'alkalescent'.

The assimilation of vegetable food to the animal nature thus became a question of turning acescent into alkalescent matter. It was possible to follow this 'animalization' along its successive stages. ${ }^{78}$ The crude food in the first passages, still retaining its plant nature, would naturally tend to turn acid, an argument used by Boerhaave in denying that the acidity of the stomach contents after a meal was of gastric origin. ${ }^{44}$ Chyle was a little nearer the true animal nature, but impracticable to get for analysis. The next stage was represented by milk, regarded as chyle somewhat further perfected by dilution with lymph and the action of the blood vessels, ${ }^{51}$ but still with a tendency to turn sour rather than alkaline. Lower had recorded, at the end of his treatise De Corde, ${ }^{79}$ that the milkiness in the blood following a meal disappears after some hours; this was interpreted by Boerhaave as the conversion of the milk into the truly animal nature of the alkalescent serum by the continued action of the body's blood vessels, viscera and humours.

To explain the mechanism of the change from something actually or potentially acid into something on the verge of alkalinity, Boerhaave naturally turned to his well-nigh universal instrument, heat. All the alkalis he knew were produced either by the intense heat of a fire or the gentle heat that induces putrefaction, ${ }^{39}$ and he often referred to the caustic sensation of alkalis on the tongue as an 'igneous' taste. Animalization, therefore, involving a turning of actual or potential acidity into potential alkalinity, was a sort of mild and incomplete version of the roasting of tartar, which taken to excess would yield the actual alkalinity of putrefied matter ${ }^{80}$ Further, via heat, Boerhaave was able to get back on the favourite hobby-horse of all the physiologists, the circulation of the blood, for he was 'certain beyond all doubt' that animal heat arises from the friction of the fluids moving in the vessels. ${ }^{81}$ Thus the proper assimilation of the food came to depend, like most things in the body, on the proper functioning of the vascular system, and an important link was forged between the chemical and mechanical viewpoints.

Another aspect of Boerhaave's view of assimilation was the increase of volatility, the salts of plants being fixed, while those obtainable from animal matter by putrefaction or heat were volatile. This feature was paralleled, not 


\section{Boerhaave's Biochemistry}

by the roasting of tartar, but by the increase in volatility of waxes on heating. ${ }^{74}$ The action of fire would, here again, complete the process begun by the animal, producing the salt that was actually volatile as well as actually alkaline. Boyle, in the light of his rather crudely mechanical corpuscular theory, had said that 'volatilization' could be achieved either by increasing the surface, as when gold is beaten into leaf so thin that it floats on water, or by applying a volatile substance, as in treating iron with sal ammoniac. Boerhaave envisaged processes of both types operating on chyle, the particles being expanded by heat and diluted by very subtle and freely mobile liquids produced by the body. ${ }^{82}$

\section{Acid-Alkali Pathology}

Many disease symptoms were referred by Boerhaave to a too vigorous or too feeble process of animalization, and in consequence a good deal of acid and alkali remained in his pathology and therapeutics. Some of the most direct corollaries of his view of assimilation, as worked out in considerable detail in the Aphorisms, are summarized below.

The motion of the liquids is due to two causes, said Boerhaave, the heart-beat and the strength and contractility of the vessels, whose function it is to react by pressing back on the fluid distending them. The firmer the vessels, therefore, the greater is this reaction and the faster does assimilation take place, provided the rigidity is not so great as to prevent the vessels yielding to the impulse of the liquids. When the fibrous structure of vessels and viscera is weak and lax, the action of the solids on the liquids is sluggish and the food is imperfectly converted into healthy body fluids-not into good blood, but only into milk, as it were; for instance, white blood has been drawn from a weakly girl languishing under a chlorosis. One remedy is to feed materials already prepared almost as in the healthy body, such as milk, eggs and meat broths, the latter best made from animals previously fasted so that nothing crude remains in them. ${ }^{83}$

Other causes disposing towards an acid acrimony include a diet containing too much mealy and succulent plant food, this being acid or acescent; a want of good blood already present, to supply the fluids that help assimilation; and a deficiency of muscular motion to quicken the circulation. ${ }^{84}$ Thus, this type of disease is commonest in infants and the slothful, who take little exercise, and in the poor, who eat a predominantly vegetable diet. ${ }^{85}$ Acidity in the first passages shows itself by sour belchings, flatulency and so on; if it also invades the blood, it there causes paleness, a chylous acid serum, sometimes acid sweat and saliva, milk that is acid or too acescent and speedily coagulable, possibly coagulation of the blood itself. Cures include, besides an alkalescent diet and exercise, various alkaline preparations, such as powder of crabs' eyes, as good as the more costly pearls for absorbing acids in the first passages, and also lixivial and volatile salts, as well as copious water to dilute the acids and oils to 'blunt' them. ${ }^{86}$

The causes of alkaline acrimony are in general the converse of the abovealkalescent diet, excess of good blood and great strength of vessels and viscera. Excessive motion of the fluids, as in acute fevers, makes them tend towards 


\section{F. R. Jevons}

putrefaction. ${ }^{87}$ So, more slowly, does stagnation, although it is an opposite cause, ${ }^{88}$ because the circulation is necessary to eliminate whatever matter, by its natural disposition, begins to putrefy. ${ }^{89}$ Probably the blood never actually putrefies in the living body, for death ensues first by destruction of the fine vessels of the brain, but it may come very near, as in putrid scurvy, when the bloody matter from the gums stinks like a dead carcass. ${ }^{90}$ 'There is often a true putrefaction in the stools, and a great disposition towards it in the urine', 91 which is 'the true lixivium of the blood, or the ablution of all the salts and oils that were growing too acrid'. ${ }^{81}$ Putrid bilious vomiting and diarrhoea ${ }^{92}$ are among the signs of the strength of the bile, the most readily alkalescent humour in the body, being 'the most animal or elaborated', formed not from ordinary arterial blood but from blood further acted on in the portal system. ${ }^{39} \mathrm{Just}$ as egg white on putrefying loses its cohesion (viscosity) and heat-coagulability, so the blood in diseases of alkalinity is 'dissolved too much', i.e. too attenuated and fine; it therefore leaks from the vessels as in dropsy and scurvy, and becomes unfit for the nourishment of the tissues, so that the body wastes, as in consumption. ${ }^{90}$ Cures include an acescent diet and acid plant products such as sorrel, vinegar and tartar. The 'acid spirits drawn by fire from sea-salt, nitre and vitriol' are even better, because these mineral acids resist putrefaction most powerfully and coagulate (thicken) the humours rather than 'dissolving' them as the vegetable acids do. Boerhaave enthused over Sydenham's use of sulphuric acid in the drink to treat smallpox, ' $a$ disease in which the whole body dissolves into the most putrid mass'.93

\section{The Spiritus Rector as Carrier of Biological Specificity}

A major criticism levelled against the Galenic humoral theory at the Renaissance was its failure to account for biological specificity. How could mere imbalance of blood, phlegm, yellow bile and black bile account for the diversity of diseases, let alone the great, yet fixed, variety of living things? Paracelsus spoke of more specific 'seeds' as formative causes of individual things, and such a concept was elaborated by Van Helmont in his search for divinely created semina responsible for specific form and function. These semina, closely related to ferments or notions of what has to be done, were immanent in matter, there being no rigid dualism of body versus spirit or soul; they were thought of as usually very fine and tenuous, and probably not unlike odours. Van Helmont's work on gases seems to have been the result of his attempts empirically to discover these vectors of specificity, volatilized, for instance, by fire or by fermentation. ${ }^{34}$

Boerhaave's concept of a Spiritus Rector or Governing Spirit bore the clear stamp of its Helmontian ancestry, though it also resembled the quintessence or concentrated active principle of alchemists such as Isaac of Holland. The Spiritus Rector, said Boerhaave, is very subtle and volatile, and to retain it in its proper body, the Creator has united it with a tenacious oil. 94 The oil of a fatty plant seed, for instance, itself too thick to enter the embryo, entangles a fine spirit of this kind, which may breathe a vital principle into the juices that 


\section{Boerhaave's Biochemistry}

nourish the embryo and stamp on it the character that distinguishes the family (species). ${ }^{95}$ The spirit can be separated from the oil by distillation with alcohol or water, or even by merely shaking with water. ${ }^{96}$ As an example, if cinnamon is distilled with boiling water, all the fragrance passes over into the distillate, and the residue, though retaining its original appearance and shape, shows no sign of the aromatic virtue peculiar to cinnamon-it is now like any other bark. If the distillate is allowed to stand in an open vessel, it too loses the fragrance, though there is hardly any loss in weight; there is thus very little of the spirit, but it is prodigiously active. 'The antient Adepts have been bold enough to pretend to measure the quantity of this Spirit, and tell us that it is $1 / 8200$ part of its seminal Body', said Boerhaave, ${ }^{97}$ quoting the curious figure given by Van Helmont. Similarly, herbs distilled at a gentle heat yield a liquor consisting mostly of simple water with the smell and taste of the plant; 'the medicinal vertue of these Waters depends chiefly upon the Spiritus Rector, which, being of a very mobile active nature, affects the Nerves ... and quickens them when they are languid'.98 Sometimes, however, the Spiritus Rector does not show itself to the senses by any marked smell or taste. ${ }^{99}$

Animals have a subtle 'exhaling spirit' which 'seems to contain that singular quality which is peculiar to every particular Animal,' and which hounds can single out and pursue. ${ }^{100}$ Some alchemists maintained that similar spirits are present in metals and minerals, but Boerhaave felt unequal to commenting on this claim. ${ }^{101}$

\section{General Assessment}

Cumston wrote of Boerhaave that 'his doctrine was a mixture of Iatromechanics and Iatro-chemistry, to which was added a small dose of Galenism. It was eclecticism made easy, and nothing more'. ${ }^{102}$ This judgment falls a good deal short of the truth if 'iatrochemistry' is given anything like its usual meaning. Much of Boerhaave's effort was directed to denying the extravagant claims of acknowledged leaders of the iatrochemical sect such as Sylvius and Willis. His refutation of the acid-alkali physiology was a valuable exposure of an absurd doctrine based on a faulty method; though on one point his enthusiasm carried him too far, for he threw out the baby of the gastric acid with the murky iatrochemical bath water.

To replace the system of physiological chemistry based on the effervescence of acid and alkali, Boerhaave expounded one based on the conversion of acescence into alkalescence. The new system was worked out with considerable care and deference to direct observation, so that, while its deficiencies are easy enough to see, its empirical and rational basis is also clear. It went appreciably further in precision than the crude analogy to fermentation used by Van Helmont. The old concept of a fermentation, dating back to the heyday of the alchemists' dream of transmutation by a philosopher's stone, included almost any deep-seated change, especially one turning other matter into the ferment's own nature. This was now rejected in favour of a more circumscribed meaning, referring specifically to the processes undergone by vegetable materials in 


\section{F. R. Jevons}

turning first into vinous, then into vinegary liquids. ${ }^{103}$ Assimilation of food by animals became less an analogue of fermentation than a preliminary to putrefaction.

Boerhaave's was perhaps the most serious attempt up to his time to come to grips with the difficulties of arguing from in vitro to in vivo conditions. Certainly his approach to this problem was far more sober than that of his iatrochemical predecessors, who were content to skate over it by glib analogies. ${ }^{104} \mathrm{He}$ did, however, neglect obvious concentration effects in a way which, one might think, could have been avoided. Thus, he was well aware of the difference in precipitating power between dilute and concentrated alcohol. ${ }^{105}$ Nevertheless, he said that 'tissues soon grow hard in Alcohol, together with their contained Humours. No wonder, therefore, that those poor Wretches who use this Alcohol, though somewhat diluted, too freely, should be obnoxious to such terrible disorders of the Nerves, and Polypus's in the Blood.'106 Similarly, he recommended common salt against alkaline diseases, for 'these salts, sprinkled on the flesh of animals, prevent putrefaction, as we learn by daily experience'. ${ }^{107}$ Again, although one cannot blame him for having no measure of acidity as precise as the modern concept of $\mathrm{pH}$, it was surely rash to attribute the flexibility of the bones in rickets to acids in the body softening them, as acids do in vitro. ${ }^{108}$ Similarly with temperature; although he exclaimed 'of what infinite use ... are Fahrenheit's mercurial Thermometers', ${ }^{109}$ he nevertheless did not hesitate to explain the corruption of the milk in the breasts of a woman in high fever by the effects observed on boiling milk with potassium carbonate. ${ }^{110}$ It is true of Boerhaave's pathological chemistry in general that it falls short of his physiological chemistry in careful reliance on observation. One is reminded of the comparable delay that was necessary for the adequate description of other aspects of the body in disease as distinct from health - the lag that separated Morgagni from the Renaissance anatomists, for instance.

After Boerhaave's, the next comparably comprehensive system of chemical physiology was perhaps that of Liebig. For all the transformation that the chemical revolution had wrought in the meantime, the two systems bear comparison. Liebig had the enormous advantage of being able to deal with elements that really remained constant in quantity, unlike Boerhaave's salts and oils. He was thus able to do what Lavoisier in his last years had begun-to set up balance sheets for biological changes. Boerhaave applied quantitative methods to substances, within the limits set by the chemistry of his time, but he did not get as far as applying them to processes. He recognized that the common salt of blood and urine derives unchanged from the diet;111 the roughest of balance experiments would have shown him that the fixed salts of plants are not the precursors of the volatile salts into which animal tissues can be resolved. On the other hand, Liebig's idea that 'all putrescible substances, in the state of putrescence, become ferments', ${ }^{112}$ for all the hints that might be read into it of the protein nature of enzymes, was a questionable advance on Boerhaave's views. Liebig knew ${ }^{113}$ that meat and vegetable diets in fact have the opposite effects on the acidity of the urine to those supposed by Boerhaave's theory. His 


\section{Boerhaave's Biochemistry}

doctrine of the alkalinity of the blood, however, represented anything but an advance; it was deduced from an analysis of the ash, ${ }^{114}$ and the alkali was supposed to 'promote and increase the combustibility of the respiratory matters', since sugars show reducing properties in alkaline solution. ${ }^{115}$

It seems appropriate to end by referring again to Boerhaave's greatest quality, his ability as a teacher. There can be no doubt that his resounding success owed much to the way he was able to fit facts from a wide range into coherent and consistent systems; and nowhere is this better shown than where his chemistry, physiology and pathology impinge on each other.

\section{NOTES AND REFERENCES}

The main works of Boerhaave are referred to as follows:

Chem. Elements of Chemistry, translated by Timothy Dallowe, 2 vols., London, J. \& J. Pemberton, 1735 .

Inst. Dr. Boerhaave's Academical Lectures on the Theory of Physic. Being a genuine translation of his Institutes and Explanatory Comment, 6 vols. Quotations are taken from vol. I of the 3 rd ed., London, I 766 and vol. mi of the Ist ed., London, I 744.

Aph. Commentaries upon Boerhaave's Aphorisms, by Baron Van Swieten, translated from the Latin, 18 vols., Edinburgh, C. Elliot, 1776.

I. Burton, W., An Account of the Life and Writings of Herman Boerhaave, London, H. Lintot, I 743, frontis.

2. Ibid., pp. 6r-3. 3 3. Ibid., p. $48 . \quad$ 4. Ibid., p. 8.

5. Ibid., pp. 15-1 7. If Haller's testimony (Lindeboom, G. A., Bibliographia Boerhaaviana, Leyden, Brill, 1959, p. 76) is to be believed, however, he had to do some hasty cramming in botany on his appointment to the professorship in 1709 .

6. Chem., Author's Dedication.

7. BURTON, op. cit., p. 27. The students involved were probably English.

8. Chem., p. vii. 9. Ibid., p. viii.

10. His best-known original contributions, the experiments on mercury, did not appear until i $734^{-6}$ (Lindeboom, op. cit., p. 86).

II. Chem., The Translator to the Reader.

12. Ibid., vol. II, p. $8 . \quad$ 13. Ibid., vol. II, p. 235.

14. Lemoine, A., Stahl et l'Animisme, Paris, Baillière, 1858, esp. pp. 30-74.

I5. Chem., vol. I, p. I8. Elsewhere, bemoaning the fact that the greatest physicians have seldom been well acquainted with chemistry, Boerhaave singles out John Bohn and Hoffman as honourable exceptions; Stahl is not mentioned (Chem., vol. I, p. 56).

16. Chem., vol. I, p. 53 .

17. Lemery, N., A Course of Chymistry, translated from the $5^{\text {th }}$ French ed. by Walter Harris, London, W. Kettelby, 1686.

18. Descartes, R., Discourse on Method, Part IV.

19. — L'Homme. In Euvres, ed. Victor Cousin. Paris, Levrault, 1824, vol. Iv, pp. $33^{8}$ and $35^{8}$.

20. BURton, op. cit., p. 91, reporting the Rectoral Oration De Comparando Certo in Physics, 1715. 
21. Ibid., pp. 77-80. Also Chem., vol. 1, p. 46. 22. Aph., § 22.

23. BU RTON, op. cit., p. 24, reporting Oratio de Commendando Studio Hippocratico, I 70 I.

24. - op. cit., p. 92. 25. Ibid., p. 25. 26. Chem., vol. 1, p. 52, for instance.

27. BURTON, op. cit., p. 96, reporting Oratio qua repurgatae medicinae facilis asseritur simplicitas, 1 709. For instance, although the laws of mechanics are certain enough, 'nothing is more uncertain than what Mechanicians assert from those general Rules concerning the human Body', the hydraulics of which is complicated by the flexibility and elasticity of the vessels and the compressibility and viscosity of the fluids flowing in them (Inst., $\S 19$ ).

28. - op. cit., p. 97. 'Carefully exclude all these from the works of Paracelsus, Helmont, Tachenius and the ancient chemists', proceeded Boerhaave, 'what have you more, than the few plain discoveries collected by the worthy Mr. Boyle with great labour, prudence, fidelity and perspicuity'. Why was Sylvius excluded from the list of iatrochemists? Elsewhere, Boerhaave did not hesitate to name his famous predecessor at Leyden as principal author of the doctrine he tore to shreds. But the occasion here was an Academic Oration, a gala occasion for the University (picture in Lindeboom, op. cit., facing p. 23); could it be that it seemed tactless to set up as a villain of the piece one of the University's most illustrious names?

29. BoAs, M., Acid and alkali in seventeenth century chemistry, Arch. Internat. Hist. Sci., 1956, 9, 13.

30. - Robert Boyle and Seventeenth Century Chemistry, Cambridge University Press, 1958.

31. Quoted from Hippocrates Chymicus, English edition, 1696, by Boas (1956), op. cit., p. 16.

32. Loos, J. J., Van Helmont, Heidelberg, Mohr \& Zimmer, 1807.

33. Foste R, M., Lectures on the History of Physiology, Cambridge University Press, Igor, Lecture V.

34. PAGEL, W., Religious and philosophical aspects of van Helmont's science and medicine, Bull. Hist. Med., 1944, Supp. 2.

35. Partington, J. R., Joan Baptista van Helmont, Ann. Sci., i936, r, 359. The idea is familiar enough in modern advertising.

36. Charleton, W., Prolegomena to his translation of van Helmont's A Ternary of Paradoxes, London, J. Flesher, W. Lee, I650, Sections 13-19.

37. An alkali, usually potassium but sometimes sodium carbonate, prepared from ashes by lixiviating or extracting with water.

38. Prepared either from the lixivium of ashes, or as 'salt of tartar' by roasting the tartar of wine (potassium hydrogen tartrate).

39. Inst., § 99. 40. Ibid., § I о I. 4I. E.g. Chem., vol. II, pp. 40 and 374 .

42. Chem., vol. II, p. 218.

43. Inst., $\S \S 66,77,99$ and Ior ; Chem., vol. II, pp. 207, 2 I I, 235 and 241.

44. Inst., $\S 77$; cf. also $\S 88$. 45. Fost E R, op. cit., Lecture VIII. 46. Inst., $\S 76$.

47. Ibid., § 68; cf. also Chem., vol. II, p. 206. We are reminded that the eating habits of those who could afford it reflected high rather than gracious living.

48. Foste R, op. cit., p. 156. 49. Chem., vol. 1, pp. 78-181. 50. Inst., § 102.

51. Chem., vol. II, p. 206. See below, under 'Assimilation of Food'.

52. Cf., however, Aph $\S 6 \mathrm{r}$ : 'Good blood contains in it materially all the other humours, bile, spittle, \&c.'

53. Inst., $\S 359$ and $\S 362$. 


\section{Boerhaave's Biochemistry}

54. Inst., $\S 394$ and $\S 402$. It was not until near the end of his life that he procured the manuscripts of Swammerdam's Bible of $\mathcal{N}$ ature, containing an experimental demonstration that the volume of a muscle does not increase during shortening. His edition of this work appeared just before his death in 1738 (Lindeboom, op. cit., p. 97).

55. Mayow, J., On Respiration and On Muscular Motion, Alembic Club Reprint No. 17 , Edinburgh, 1907, esp. pp. 208 and 247.

56. Inst., § 408. 57. Chem., vol. r, p. 78.

58. Inst., $\S 29$; also $\S 19$. The 'torture of fire' may be preceded in analysis by fermentation or putrefaction to 'open' the substance (Inst., § 66).

59. For instance, Woodger, J. H., Biological Principles, London, Kegan Paul, Trench and Trubner, 1929, pp. 287 and 294.

6o. Lemery, op. cit., Preface; cf. also p. 7 .

61. Chem., vol. II, p. 7. 62. Chem., vol. I, p. 40; also p. 46. 63. Chem., vol. II, p. 3 .

64. Chem., vol. II, pp. 66 and 85. 65. Lemery, op. cit., p. 2. Essentially these five principles had been proposed by Basso in 1621 (Partington, J. R., A History of Chemistry, London, Macmillan, I96r, vol. II, p. 306).

66. Chem., vol. II, p. I 10. 67. Chem., vol. II, p. 20. 68. Chem., vol. I, p. 27.

69. Chem., vol. II, pp. 235-47.

70. Chem., vol. II, p. 96. Similar remarks have often been made even since 'philosophy by fire' turned into combustion analysis for carbon and hydrogen.

71. Chem., vol. II, p. 21 . 72. E.g. Chem., vol. I, p. 44; and vol. II, p. 247.

73. Chem., vol. II, pp. 239 and 247.

74. Chem., vol. II, p. 108. Such attenuation, supposed to render the substance more penetrating, was often a major purpose in the preparation of medicines.

75. Chem., vol. II, pp. 24-7. 76. Chem., vol. I, p. 4I ; and vol. II, p. 2.

77. Chem., vol. II, pp. 93-9. 78. Aph., \$§ 25, 28, 58, etc.; Chem., vol. II, p. 204.

79. Lower, R., Tractatus De Corde, London, Jo. Redmayne for J. Allestry 1669, pp. 217-19. (Facsimile edition with translation by Franklin, K. J., in Gunther, R. T., Early Science in Oxford, vol. Ix. Oxford University Press, 1932.) Lower had similarly regarded milk as chyle filtered off from the blood before complete assimilation, but his ideas about the nature of the transformation into serum were much vaguer; he looked on it as a breaking-up of the chyle into finer particles by vital spirit and other active principles in the blood.

80. While the conversion of acid into alkali was quite familiar, the reversal of this process was unknown to Boerhaave. This was an additional argument against acidity in the gastric and pancreatic juices and the nervous fluid, the precursor of which would have to be the alkalescent serum (Inst., $\S \S 88,101$; Chem., vol. II, p. I55).

81. Aph., § roo. 82. Inst., § 95. 83. Aph., §§ 25, 44. 84. Aph., § 61.

85. Aph., $\S 68$. Also in virgins, 'because they have a more lax habit of body, and are too much given to a sedentary life, if they be of the richer sort; and those that are poor get their living by some sedentary work, and delight too much in drinking warm tea, \&c. at least in this country'.

86. Aph., $\S \S 62-6$. 87. Aph., $\S 84$ and $\S$ roo. 88. Aph., $\S 84$ and $\S 90.89$. Aph., $\S 26$. 90. Aph., § 86. 91. Aph., § 89. 92. Aph., § 85. 93. Aph., § 88.

94. Chem., vol. I, p. 47. 95. Chem., vol. I, p. 38. 96. Chem., vol. II, p. 91. $3^{61}$ 
97. Chem., vol. r, p. 48.

98. Chem., vol. In, p. ro. The empirical basis of this contention will be denied only by those who have never tried the effect of a few dabs of rose-water on the forehead and behind the ears at the end of a heavy banquet.

99. Chem., vol. 1, p. 15. 100. Chem., vol. I, p. 42. 101. Chem., vol. 1, p. 49.

102. Gumston, G. G., Introduction to the History of Medicine, London, Kegan Paul, Trench and Trubner, 1926, p. 333. Many other authorities have delivered similar verdicts. GAR RISON, F. H., Introduction to the History of Medicine, $4^{\text {th }}$ ed., Philadelphia, Saunders, 1929, p. $3^{1} 5$ quotes Albutt's opinion that Boerhaave 'seems to have contented himself with hashing up the partial truths and the entire errors of his time'. Drummond, J. C. and Wilbraham, A. (The Englishman's Food, 2nd ed., London, Jonathan Cape, 1957, chap. XII) summarize the pervasive influence of the theory of acescence and alkalescence later in the eighteenth century, but do not trace it to Boerhaave, stating that 'an early reference to the theory is to be found in Dr. John Arbuthnot's Essay Concerning the Nature of Aliments (1731)' (op. cit., p. 236).

103. Chem., vol. II, p. I I 5 ; cf. Inst., § 99 .

104. The problem had really reared its ugly head only in the fairly recent past, for not until the seventeenth century did the conviction come that non-living things are easier to understand than living ones. Before that, analogies drawn the other way round had been at least as popular, as shown, for instance, in the strong hylozoic tradition of alchemy.

105. Chem., vol. II, p. 238.

106. Chem., vol. In, p. 246. The comma after 'diluted' has been added to make clearer what must be the correct meaning.

107. Aph., § 88. Virtually the same argument was used by Paracelsus in preparing an elixir of salt that 'so fixes the body that it becomes permanent in life'. (Archidoxies, Book 8, in Hermetic and Alchemical Writings, translated by A. E. Waite, London, Elliott, I894, vol. II, p. 73.)

108. Aph., § 62.

I09. Chem., vol. In, p. 245. He even persuaded Fahrenheit to make him special thermometers (Chem., vol. I, p. 87).

I I 0. Chem., vol. II, p. 209. II I. Chem., vol. II, pp. 217 and 247.

I 1 2. Lie BIG, J., Familiar Letters on Chemistry, 4th ed., translated by J. Blyth, London, Walton \& Maberly, 1859, p. 210.

I13. Ibid., p. 409. I14. Ibid., p. 407. I I5. Ibid., p. 419. 